\title{
Entrepreneurs On Entrepreneurship: A Research Structure Based On 12 Practitioner Case Studies
}

John Zimmerman, University of Southern Nevada, USA

\begin{abstract}
The importance of entrepreneurship for economic growth and social advancement is well established, but most scholars do not agree on a structure for organizing its study. As a result, a great deal of scholarly effort in the field is often criticized as noncumulative, disorganized, and lacking predictive capability. Additionally, connections with important sub domains such as social and sustainable entrepreneurship are not well established. Advancement in the organization of the research domain can potentially lead to improved formulation of research questions, better selection of methodologies employed, and enhancements in the ability of researchers to deal more effectively with the multidisciplinary and process nature of the field. This paper uses qualitative research methodology to analyze data collected from semi structured interviews with practitioner entrepreneurs to advance a structure for future research in the field. A conceptual framework for organizing the research domain of entrepreneurship is developed through analysis of the insights and experiences from 12 case studies of practitioner entrepreneurs, leading to the identification of a proposed structure based upon four categorical dimensions of an entrepreneurship conceptual framework - procedural, typological, behavioral, and environmental.
\end{abstract}

Keywords: Entrepreneurship model, entrepreneurship theory, entrepreneurship research framework, entrepreneurship case study.

\section{THE IMPORTANCE OF ENTREPRENEURSHIP}

"Never doubt that a small group of thoughtful, committed citizens can change the world. Indeed, it is the only thing that ever has." - Margaret Mead

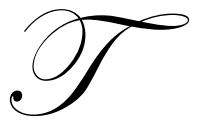

here can be little doubt of the power of entrepreneurship; it is arguably the most significant force in both creating and sustaining economic growth and social mobility (Timmons \& Spinelli, 2009). Since most small businesses are entrepreneurial endeavors, their growth is often used as a proxy to quantify the impact of entrepreneurship in the United States. The seminal work of David Birch long ago established the significance of small businesses as the driving economic force in job creation. Birch established that companies with less than 100 employees accounted for 81.5 percent of the net new jobs created from 1969 to 1976 (1979). More recent data is equally, if not more, compelling. According to the United States Small Business Administration's Office of Advocacy, independent businesses with less than 500 employees account for 99.7 percent of all businesses and employ 50 percent of all private sector employees. In 2006, small businesses accounted for almost $45 \%$ of private US payrolls; created over 50 percent of all nonfarm private gross domestic product (GDP), produced 28.9 percent of known export value (2006), and generated 13 times the number of patents per employee than large firms. These small entrepreneurial firms have produced 60 to 80 percent of net new jobs annually over the last decade (Small Business Administration Office of Advocacy, 2008).

Other data confirm the power of entrepreneurship in advancing social mobility. Of 23 million nonfarm businesses in 2002, 6.5 million (28 percent) were owned by women. These women-owned firms generated $\$ 940.8$ 
billion in revenues, employed 7.1 million workers, and paid $\$ 173.7$ billion in payroll (Lowrey, Office of Economic Research, 2004). Minority small business activity is equally impressive. In 2002 minorities owned 4.1 million firms, or 18 percent of the 23 million nonfarm businesses in the US, generating $\$ 694$ billion in revenues, and employing 4.8 million workers (Lowrey, Office of Economic Research, 2007).

The data confirming the power of entrepreneurship in the United States is undeniable, but what about international entrepreneurship? One respected source of international entrepreneurship activity is the Global Entrepreneurship Monitor (GEM). GEM was founded and is sponsored by Babson College and the London Business School. Their 2007 Executive Report contains data from 42 participating countries. GEM data is segregated between high-income countries in Europe, Asia and the United States; middle and low-income countries from Europe and Asia; and middle and low-income countries from Latin America and the Caribbean. Unlike other research, GEM takes a broad view of entrepreneurship focusing on the roles taken by individuals in the process rather than small firms. Despite these differences in methodology, the GEM data also confirms the power of entrepreneurship (Bosma, Jones, Autio, \& Levie, 2008). In the high-income country classification, the share of the adult population aged 18 to 64 engaged in entrepreneurship ranged from $4.8 \%$ (France) to $19.8 \%$ (Iceland), with the United States at $14.1 \%$. In the middle and low-income in Europe and Asia segment, entrepreneurial activity ranged from $4.3 \%$ (Russia) to $47.4 \%$ (Thailand). In the Latin and Caribbean middle and low-income countries, activity ranged from $18.5 \%$ (Uruguay) to $39.0 \%$ (Peru).

There can be little doubt of the importance and global nature of the phenomenon of entrepreneurship. There is also much anecdotal evidence supporting its significance. For example, data from a variety of sources shows that during the $20^{\text {th }}$ century the world's population more than quadrupled from 1.6 billion to more than 6 billion, yet global economic output increased by 15 times, while at the same time the average workweek declined by $12 / 3$ days. Concurrently, in most of the world, the workplace became more open for women and minorities, and some diseases were greatly controlled or even eliminated. Is it possible that this social and economic advancement could have occurred without the influence of the entrepreneur?

Margaret Mead was correct - small groups of committed individuals, such as entrepreneurs - can and do change the world.

\section{THE SCHOLARLY VIEW}

The evolution of the study of entrepreneurship is intriguing, fascinating, and interesting. Scholarly thought about entrepreneurship has its origins in economics. From Cantillon (1755) who characterized entrepreneurs as intermediaries who undertake risk; to Schumpeter (1934) who added entrepreneurship as one of the factors of production, and created the notion of creative destruction; to Cole (1959) who defined the entrepreneurial task as creating profits through the commercialization of innovation, and provided a transition to the fields of sociology and psychology through his work on motivation and change; economists have provided the foundation for study in the field. The fields of sociology and psychology have supplied significant insights as well, such as McClelland's (1961) suggestion that psychological traits present in entrepreneurs have predictive ability. Although later refuted by some researchers (Gartner, 1989), McClelland's work did advance what is known about the psychology of entrepreneurs, leading to important work on entrepreneurial intentions (Bird \& Jelelnick, 1988), as well as analytically and psychoanalytically oriented research by Landstrom (1999).

Recent research emphasizes the need for a multidisciplinary, process approach. Gartner, Shaver, et. al. (2004), Bygrave and Hofer (1991), and Shane (2003) stress the significance of studying entrepreneurship as an interdisciplinary process while at the same time observing the complexity of doing so. Shane (2003) concludes that "any effort to provide a conceptual framework seems to require an interdisciplinary approach" (p. 10). Shane also rightly contends that entrepreneurship is a process that is influenced by "individual-, institutional-, and industrylevel factors" (p.10).

Davidsson (2004) further advances the discussion of the field by adopting an interesting and somewhat unique perspective. He distinguishes between definition, theory, and a research domain; arguing that delineating a 
scholarly domain is more useful to the researcher. He goes on to suggest that Shane \& Venkatarman's (2000) definition of the scholarly domain of entrepreneurship as perhaps the most compelling to date:

[T] he scholarly examination of how, by whom, and with what effects opportunities to create future goods and services are discovered, evaluated, and exploited (Venkatarman, 1997). Consequently the field involves the study of sources of opportunity; the processes of discovery, evaluation, and exploitation of opportunities; and the set of individuals who discover, evaluate, and exploit them (p.218).

Hirsch \& Peters (1989) characterize entrepreneurship as a process, but add the notion of personal gratification to that of monetary reward, thereby allowing the sub domains of sustainable and social entrepreneurship to be connected to the field. Scholars such as Dees (1998) and Yunus (2007) who study social entrepreneurship; as well as Krueger (2005), who focuses on sustainable entrepreneurship, continue to make significant and meaningful contributions in these areas. Zahra (2005) points out that "scholars (Davidsson, 2004; Gartner, 1990, 2002; Low, 2002; Low \& MacMillan,1988) have accepted the proposition that there are different sub domains [of entrepreneurship] that are loosely connected" (p. 254). Zahra goes on to note that these same scholars maintain that while this conversation has endured for nearly three decades now, the lack of linkages in sub domains has contributed to the field lacking substance, and systematic and thoughtful scholarship.

Despite the contributions of these scholars, many academicians remain frustrated with progress. Some scholars observe that rather than explaining and predicting a unique set of empirical phenomena, entrepreneurship has become a broad label where a mixture of research resides (Shane \& Venkataraman, 2000). There several reasons noted for this frustration. First, the interdisciplinary nature of the phenomenon has resulted in researchers in the field borrowing definitions and theories from other sciences. Second, research in the field has often used methodologies from other domains that are well suited to studying one dimension at a time, but are not well suited to understanding entrepreneurship as a process (Bygrave, 1989).

As a result, research in the field often appears disorganized, with some scholars noting that the study of entrepreneurship lacks definition, focus, and a conceptual structure (Shane \& Venkataraman, 2000). This lack of a conceptual framework that can explain and predict a set of empirical phenomena has resulted in the field of entrepreneurial research becoming a disorganized and even confusing storage location for a variety of research in economics, finance, organizational behavior, and psychology, among others. There can be little doubt that the lack of a consensus for a common conceptual framework for entrepreneurship has hampered the progress of research (Bygrave \& Hofer, 1991). In fact, many scholars go even further and maintain that entrepreneurship is not a distinctive field of study, with results that are fragmented and noncumulative (Schildt, Zahra, \& Sillanpa, 2006).

An accepted structure for organizing research in entrepreneurship should be helpful in order to improve research design and select methodologies (Davidsson, 2004). Additionally, an accepted structure can make investigation into important sub domains such as social entrepreneurship and sustainable entrepreneurship more effective.

Since this ongoing debate is among the scholarly community, perhaps it would be useful to ask practitioner entrepreneurs what they think about what it is that they do.

\section{ENTREPRENEURS ON ENTREPRENEURSHIP}

This study gives voice to practitioner entrepreneurs to assemble a structure for research into the field. Twelve case studies were developed from a series of semi-structured interviews that are used to develop a proposed organization for entrepreneurship research

The research design calls for practitioner entrepreneurs to be active participants in, rather than subjects of, the research. By working collaboratively through a series of in person interviews data is collected and analyzed to discover a structure for future studies. Interview topics were selected from a composite of the work of several scholars (Bygrave \& Hofer, 1991; Gartner, 2002; Shane, 2003; Venkataraman, 1997). These topics consisted of Demographics and Background (DEM), Opportunity Recognition (OR), Innovation (IN), Triggering Event (TE), Risk and Uncertainty (RU), Start-Up Process (SU), Financing the Venture (FNV), Social Behavior and Context 
(SBC), Social Networks (SN), Environmental (EN), Growth and Stability (GS), Exit Strategy (ES), and Any Other New Dimension Identified (SUM). The topics informed and guided the interviews, but were not shared with the participants to attempt to avoid any bias. Purposeful sampling was employed in order to ensure a representative cross section of various types of entrepreneurs, and qualitative research methodology techniques were used as informed by the work of Strauss and Corbin (1998). The study sample size selection was based on the work of Creswell (2003), who suggests 10 to 15 participants should be initially selected. The characteristics used to select each participant were informed by the work of several scholars (Bygrave \& Hofer, 1991; Gartner, 2002; Shane, 2003; Venkataraman, 1997), are listed below:

1. Nascent Entrepreneur - one who is undertaking their first experience as an entrepreneur.

2. Intrapreneur - one who undertakes entrepreneurship inside an established organization.

3. Small Business-an entrepreneur who employs less than 50 workers.

4. Large Business - an entrepreneur who employs more than 500 workers.

5. Medium Business - an entrepreneur who employs less than 50 but not more than 500 workers

6. Immigrant - an entrepreneur who has immigrated to the United States to start a venture.

7. Minority - an entrepreneur from one of the protected classes as defined by The U.S. Equal Employment Opportunity Commission.

8. Investor - a venture capital or angel investor.

9. Public Policy—a governmental official who influences entrepreneurship policy.

10. International - an entrepreneur whose endeavor is global in scope.

Twenty-five participants were contacted and evaluated, and 13 who met the parameters for sample selection agreed to participate in the study. In one case, two partners collaborated to launch one new venture and were considered as one case study. In person interviews of 2 to 4 hours were conducted at the entrepreneur's location and follow-up sessions were held where clarification was needed. Data gathering and analysis was completed using replication logic (Eisenhardt, 1989). Note taking was used to document the interviews, and memoing was deployed as documentation. Insights from each interview were developed into a separate case study, and then the 12 case studies were cross-coded, -analyzed, and -synthesized into emergent themes. To ensure reliability and validity, before data collection was initiated, six academic researchers reviewed the sample selection, interview topics, data gathering, and data analysis methodology. Two trial interviews with non participants were also conducted and analyzed. After data collection and analysis was completed, four data analysis tests to improve reliability and validity were deployed (Huberman \& Miles, 2002). First, in order for it to be significant and included as evidence, more than one participant was required to mention an insight, and that participant must have been able to support the insight by providing experiential examples. Second, the mention of any insight or identification of an emergent theme resulting from data analysis in the literature was not deemed as confirmation of validity. Third, an insight from a participant was not counted as evidential if it was in dispute by another participant. Finally, one knowledgeable scholar performed an independent review to confirm the initial data analysis, and identification of emergent themes.

\section{FINDINGS}

All of the 13 participants were actively engaged in a significant dimension of entrepreneurship at the time of the interviews and collectively had more than 100 years of entrepreneurial experience. Ten operated for-profit ventures as founders, partners, and/or chief executive officers; one was a former venture capital investor and adjunct entrepreneurship professor; one is a chief executive for a nongovernmental agency promoting entrepreneurship and has experience with entrepreneurship inside a major corporation; and one had founded a not-for-profit venture. The smallest for-profit entrepreneurial endeavor had \$1 million in annual revenue, and the largest had more than \$400 million in annual revenue, with significant international operations. The educational levels of the participants varied significantly; one being a high school graduate, nine having undergraduate degrees, and three having advanced degrees. The participants were a diverse group; six were minorities, with one an immigrant. A table of the participants and their assigned pseudonym is provided in Appendix A.

The emergent themes from the analysis of the 12 case studies developed from the participant interviews coalesced into 4 categories - procedural, typological, behavioral, and environmental. 


\section{Procedural - Opportunity Recognition/Creation Plus Action}

The participants all specifically mentioned that the entrepreneurial process began with the recognition and/or creation of an opportunity through innovation or invention, but stressed that for entrepreneurship to occur, the individual(s) must act on the opportunity. The participants observed that opportunity recognition often was characterized by innovativeness, while opportunity creation was more aligned with invention. This innovativeness could be in the form of a new product or service, a means of organizing, a method of financing, or simply a unique way of implementation. The participants noted that entrepreneurial experiences are event-driven phenomena, determined by a collision of recognition or creation of opportunity, with purposeful action. This decision to act was often motivated by some meaningful personal and emotional event. One participant called this point-in-time their genesis moment, when the motivation to move forward materialized.

Opportunity recognition/creation is present in the literature. A number of authors have noted opportunity recognition as necessary for the fundamental beginning of the process (Christensen, Madsen, \& Peterson, 1994). Hills and Singh (2004) note that opportunity recognition is an important step in any business life cycle and may not be limited to entrepreneurship, and Bygrave (2004) emphasizes opportunity recognition as an important event for the founding of any entrepreneurial organization. A number of other scholars have conducted significant research into opportunity recognition (Christensen, et.al., 1994; Christensen \& Peterson, 1990; Stevenson \& Jarillo-Mossi, 1986; Timmons \& Spinelli, 2009). A great deal of this research has focused upon any traits or behaviors intrinsic to opportunity recognition. One example of work in this area of entrepreneurial action and the genesis moment can be found in the four-step process developed by Gaglio and Taub (1992), who characterize the process as the precognition stew, the eureka experience, further development of the idea, and the decision to proceed.

\section{Typological - Type of New Venture is Important}

Five categories or types of entrepreneurial ventures emerged from this research: social, intrapreneur, lifestyle, middle market, and liquidity event. Social entrepreneurial organizations have social advancement or welfare as their objective rather than profits. Intrapreneurial endeavors are entrepreneurial activities inside large organizations. Lifestyle ventures are established to create a certain desired way of life for the founder(s). Middle market ventures do not have a liquidity event as an objective, and often have growth intentionally constrained by founders to limit complexity or risk. Liquidity event seeking ventures typically are venture capital financed and have the objective of a transaction returning invested capital plus an acceptable return to investors as an exit strategy. These classifications potentially can be useful to researchers because they facilitate a discussion of differences in entrepreneurial motivations and intentions, and can assist in analysis of differences in the financial, managerial, marketing, and operational strategies deployed. Using financial strategy to illustrate this point, lifestyle entrepreneurs in the study more often used bootstrap capital (second mortgages, savings, and funds from family); middle market ventures used a combination of bootstrap capital and small business loans; while liquidity event startups used primarily venture and/or angel capital.

Academic work relevant to a typology for entrepreneurial endeavors is discussed by Hisrich (1989), who discusses lifestyle and liquidity event endeavors, and Miller (1983) who identified three management structure types of entrepreneurial firms: simple, which are small with centralized power at the top; planning, which are bigger, with a goal of smooth and efficient operation through the use of formal controls and plans; and organic, which are those that strive to be adaptive to their environments, emphasizing expertise-based power and open communications. Certain scholars have identified entrepreneurship in large corporations, or intrapreneurship (Cunningham \& Lischeron, 1991), and social entrepreneurship (Dees, 1998; Yunus, 2007), but there is minimal work about what a particular form of entrepreneurial endeavor may mean to the strategic, financial, operational, marketing, and human resources practices employed in the new venture formation process. A great deal of research does exist concerning the financing of entrepreneurial endeavors, but focuses on the source and type of financing and how this affects strategies for fund-raising (Acs \& Audretsch, 2005), or how entrepreneurs evaluate various sources of capital (Myers, 1984). Other scholars are interested in venture capital and angel capital as it may impact new venture formation (Admati \& Pfleiderer, 1994; Gompers \& Lerner, 2003). 
Other types of entrepreneurship not noted in the present research most probably exist. For example in underdeveloped economies, subsistence entrepreneurship may exist. Here entrepreneurial activity may be undertaken for survival purposes leading to a possible sixth type. There may be other typologies present such as entrepreneurship in unionized organizations, entrepreneurship in non-capitalistic socio-economic systems, international entrepreneurship, or sustainable entrepreneurship for example.

The typology of entrepreneurship is important for organizing a conceptual framework because it provides a logical area for scholars to study sub domains such as social entrepreneurship and sustainable entrepreneurship, and for analyzing any impact of type on strategies deployed.

\section{Behavioral - Born or Made is the Wrong Question}

Behavior employed immerged as more significant than innate or natural personality traits or characteristics, with a strong belief system, grounded in personal values, serving as the foundation for these behaviors. First, selfawareness, or the ability to objectively and dispassionately know one's own weaknesses or strengths was noted as a critical behavior. Self-discipline, where the participants engaged in key activities that were deemed essential for the success of their venture, even though they may be unpleasant or undesirable, was a second critical behavior. Third, accountability was mentioned by the participants, with strong experiential examples of this accountability, not just to themselves, but to their employees and their employees' families for example. Finally, intellectual honesty and curiosity were noted. A passion to learn and grow, and the ability to face the realities of their ventures were seen as critical behaviors important to entrepreneurial success.

A great deal of entrepreneurship research in this area of traits or characteristics of entrepreneurs has been conducted by psychologists and sociologists. Weber (1904) may have initiated the dialogue when he identified the sense of industriousness, self-denial, thrift, and duty as traits that contribute to economic development. The work of McClelland (1986) generated the theory of the need for achievement, a learned behavior generated by a predilection toward self-reliance. He went on to assert that there are certain traits-need for achievement, having strong selfconfidence, possessing independent problem-solving skills, a preference for situations of moderate risk, actively seeking feedback, and accepting individual responsibility - that constitute the primary traits of an entrepreneur. A number of academicians have refuted these claims. Gartner (1989) argues that traits are not enough; to be an entrepreneur one must create an organization. Others criticized the trait theory of entrepreneurship because it is based in simplistic assumptions of personality and behavior (Carsrud \& Krueger, 1995), or pointed out that any correlation between traits and venture performance is difficult to establish (Herron, 1990). On the other hand, Fisher and Koch (2008) assert that "both genetic evidence and survey data support the notion that a substantial portion of entrepreneurial behavior is genetically determined" (p. 2). Other researchers believe that at this stage, there is no clear scientific personality profile of the entrepreneur (Filion, 1997). The present research based on 12 case studies of 13 practitioner entrepreneurs does not presuppose that either position is correct, and does provides some evidence that certain specific behaviors are seen as important, whether or not these behaviors are the result of innate traits.

\section{Environmental - The Ecology of New Venture Formation}

The participants believed that certain environmental or ecological factors are important for entrepreneurial ventures. These were the presence of a strong education system including a research university, a capable legal system, and a vibrant economy. The presence of a strong education system was seen as critical to ensure a reliable supply of trained employees, particularly important for lifestyle and middle market start-ups; while research universities were mentioned as vital to ensure a stream of innovative or inventive technologies, leading to products or service opportunities for liquidity event ventures. A system of law was noted as an important environmental factor in the United States (US) that is often not available in other countries. The US system of law protects property rights, providing the ability for entrepreneurs to protect their intellectual property, and enabling the formation of appropriate form of legal entities, facilitating access to capital through organized public securities markets, and allowing the systematic enforcement of contracts - factors often not available in some other countries. There are several locations in the US that illustrate the significance of environmental factors is the success of entrepreneurial activity. For example, in Silicon Valley the research activities at nearby Stanford University and the University of California Berkeley (Lee, Miller, \& Handcock, 2000) have provided many technologies, attracting the 
capital and talent that have led to a number of successful ventures.

\section{A FRAMEWORK FOR ENTREPRENEURSHIP}

The practitioner entrepreneurs saw their activities as the recognition or creation of an opportunity, resulting from innovation or invention; coupled with action by an individual or group of individuals, to form certain types of ventures. This decision to act is often generated by a personally motivated genesis moment. They noted certain personal values based behaviors - self-awareness, self-discipline, accountability, intellectual honesty, and intellectual curiosity - that entrepreneurs practice as more important than any innate personality traits. The practitioners recognized certain environmental factors - a predictable system of law, a capable education system including a research university, and a vibrant economy as significant. The four themes - procedural, typological, behavioral, and environmental - help to form the basis for a proposed conceptual framework for the field of entrepreneurship. This framework is depicted is Table 1 below:

Table 1

A Framework for the Study of Entrepreneurship

\begin{tabular}{|c||c|c|c|c|}
\hline Dimension & Procedural & Typological & Behavioral & Environmental \\
\hline \hline & $\begin{array}{c}\text { Opportunity Recognition } \\
\text { or Creation }\end{array}$ & Social & Personal Values & Legal System \\
Innovation or Invention & Lifestyle & Self-Awareness & Education System \\
$\begin{array}{c}\text { Thirteen } \\
\text { Practitioner } \\
\text { Entrepreneurs }\end{array}$ & Genesis Moment & Intrepreneur & Self Discipline & Research University \\
& Action & Middle Market & Intellectual & Vibrant Economy \\
& & Liquidity Event & Intellectual Honesty & \\
\hline \hline Unit of Analysis & The Process or the Act & The Venture & The Entrepreneur & The Ecosystem \\
\hline
\end{tabular}

\section{FUTURE RESEARCH AND LIMITATIONS}

This study is a beginning effort to use the insights from practitioners to organize future research in entrepreneurship. The sample size, the purposeful selection, and the reliance on the researcher as the primary data analyst are all potential limitations. The present research, while exploratory in nature, does offer a structure that may be useful in future research design. This study has two principle implications for future research. First, the richness of the case study method for exploring the activities of practitioners as a data source should be noted. This methodology enables researchers to more completely deal with the multidisciplinary and process nature of entrepreneurship. Finally, the suggested framework emerged from the case studies that may allow researchers to better organize future inquiry, formulate research questions, and form collaborations with researchers from various fields.

\section{AUTHOR INFORMATION}

Dr. Zimmerman holds a bachelor of business administration from Ohio University, majoring in management, a masters in business administration from Xavier University (Cincinnati, Ohio) majoring in international finance and a doctorate in organizational leadership with a specialization in entrepreneurship from Pepperdine University.

His professional career includes senior management positions with General Electric Company, and Caterpillar Tractor Company and Intel Corporation. Dr. Zimmerman was also chief financial officer for Level One Communications, a startup company that completed initial and secondary public offerings, and where he assembled 
a successful finance and administrative staff and completed several strategic transactions and acquisitions, and iSuppli Corporation, a supply chain and market intelligence company.

Dr. Zimmerman has taught MBA courses as an adjunct professor at Pepperdine University's Graziadio School of Business and Management and currently teaches entrepreneurship at the University of Southern Nevada.

\section{REFERENCES}

1. Acs, Z., \& Audretsch, D. (2005). Handbook of entrepreneurship research. New York, NY: Springer ScienceBusiness Media.

2. Admati, A., \& Pfleiderer, P. (1994). Robust financial contracting and the role of venture capital. Journal of Finance, 49, 371-402.

3. Birch, D. L. (1979). The Job Creation Process. Washington, DC: MIT Program on Neighborhood and Regional Change prepared for the Economic Development Administraion, U.S. Department of Commerce.

4. Bird, B., \& Jelelnick, M. (1988). The operation of entrepreneurial intentions. Entrepreneurship Theory and Practice , 13 (2), 21-29.

5. Bosma, N., Jones, K., Autio, E., \& Levie, J. (2008). Global Entrepreneurship Monitor. Babson Park and London: Babson College and Lodon Buiness School.

6. Bygrave, W. D., \& Hofer, C. W. (1991). Theorizing about entrepreneurship. Entrepreneurship Theory and Practice , 16 (2), 13-22.

7. Bygrave, W. (2004). The entrepreneurial process. In W. Bygrave, \& A. Zacharakis, The portable MBA in entrepreneurship (pp. 27-42). Hoboken, NJ: Wiley \& Sons, Inc.

8. Bygrave, W. (1989). The entrepreneurial paradigm (1): A philosophical look at its research methodlogies. Entrepreneurship Theory and Practice, 14 (1), 7-26.

9. Cantillion, R. (1755). Essai sur la nature du commerce en general. New York: August M. Kelly Publishers.

10. Carsrud, A., \& Krueger, N. (1995). Entrepreneurship and social psychology (Vol. 2). Greenwich, CT: JAI Press.

11. Christensen, P. S., Madsen, O. O., \& Peterson, R. (1994). Conceptualizing entrepreneurship opportunity recognition. In G. Hills, Marketing and entrepreneurship: Research ideas and opportunities (pp. 61-75). Westport, CT: Quorum Books.

12. Christensen, P., \& Peterson, R. (1990). Opportunity identification: Mapping the sources of new venture ideas. 11th Annual Babson College Entrepreneurship Conference. Aarhus, Denmark.

13. Cole, A. (1959). An approach to the study of entrepreneurship. In F. C. Lane, \& J. C. Riesmersma, Enterprise and secular change: Readings in economic history (Vol. 6, pp. 183-184). Homewood: Irwin.

14. Creswell, J. (2003). Research design: Qualitative, quantitative, and mixed method apporaches. Thousand Oaks, CA: Sage Publications.

15. Cunningham, J., \& Lischeron, J. (1991). Defining entrepreneurship. Journal of Small Business Management , January, 45-61.

16. Davidsson, P. (2004). Researching Entrepreneurship. New York: Springer Science+Business Media.

17. Dees, J. G. (1998). The meaning of "social entrepreneurship". Kansas City, MO: The Kauffman Center for Entrepreneurial Leadership.

18. Eisenhardt, K. (1989). 1989. Building theories from case study research. Academy of Management Review , 14 (4), 532-550.

19. Filion, L. (1997). From entrepreneurship to entreprenology. San Francisco, CA: Paper presented at the 42nd ICSB World Conference.

20. Fisher, J., \& Koch, J. (2008). Born not made: The entrepreneurial personality. Westport, CT: Praeger Publishers.

21. Gaglio, C. M., \& Taub, R. P. (1992). Entrepreneurs and opportunity recognition. In N. C. Churchhill, S. Birley, W. D. Bygrave, D. E. Muzyka, C. Wahlin, \& W. E. Wetzel, Frontiers of entrepreneurship research (pp. 136147). Wellesley, MA: Babson College.

22. Gartner, W. B. (2002). Is there an elephant in entrepreneurship research? Entrepreneurship Theory \& Practice, $25(4), 11-32$.

23. Gartner, W. B. (1989). Some suggestions for research on entrepreneurial traits and characteristics. Entrepreneurship Theory and Practice (Fall), 27-37.

24. Gartner, W. B., Shaver, K. G., Carter, N. M., \& Reynolds, P. D. (2004). Handbook of Entrepreneurial Dynamics: The process of business creation. Thousand Oaks: Sage Publications.

25. Gartner, W. (1990). What are we talking about when we talk about entrepreneurship? Journal of Business Venturing , 5, 15-28. 
26. Gompers, P., \& Lerner, J. (2003). Equity financing. In A. Achs, \& D. Audretsch, Handbook of entreprenruship research (pp. 267-298). Thousand Oaks, CA: Sage Publications.

27. Herron, L. (1990). The effects and characteristics of the entrepreneur on new venture performance. Columbia, SC: Columnia College of Buisness Administration, University of South Carolina.

28. Hills, G., \& Singh, R. (2004). Opportunity recognition. In W. B. Gartner, N. M. Shaver, N. M. Carter, \& P. D. Reynolds, Handbook of entrepreneurship dynamics (pp. 259-272). Thousand Oaks, CA: Sage Publications.

29. Hisrich, R. D., \& Peters, M. P. (1989). Entrepreneurship: Starting, developing and managing a New enterprise. Homewood, IL: Irwin.

30. Huberman, A. M., \& Miles, M. B. (2002). The qualitative reseacher's companion (Eds.). Thousand Oaks, CA: Sage Publications.

31. Krueger, N. F. (2005). Sustainable entrepreneurship: Broadening the definition of "opportunity". Entrepreneurship in a Diverse World. Indian Wells, CA.

32. Landstrom, H. (1999). The roots of entrepreneurship research. The New England Journal of Entrepreneurship , 2, 9-20.

33. Lee, C., Miller, W., \& Handcock, M. (2000). The Silicon Valley edge: A habitat for innovation and entrepreneurship. Palo Alto, CA: Stanford University Press.

34. Low, M. B., \& MacMillan, I. (Journal of Management). 1988. Entrepreneurship: past research and future challenges, $14,139-161$.

35. Low, M. (2002). The adolesence of entrepreneurship research: specification of purpose. Entreprenruship Theory \& Practice, 25 (4), 17-25.

36. Lowrey, Y. (2004). Office of Economic Research. Retrieved October 22, 2008, from Office of Advocacy U.S. Small Business Administration: www.sba.gov/advo/research/rs280.pdf

37. Lowrey, Y. (2007). Office of Economic Research. Retrieved October 24, 2008, from Office of Advocay: www.sba.gov/advo/research/rs298.pdf

38. McClelland, D. C. (1961). The achieving society. Princeton: Van Nostrand.

39. McClelland, D. (1986). Characteristics of the successful entrepreneur. Third Creativity, Innovation, and Entrepreneuruship Symposium. Framingham, MA.

40. Miller, D. (1983). The correlates of entrepreneurship in three types of firms. Management Science , 29 (7), $770-$ 791.

41. Myers, S. (1984). Presidential address: The capital structure puzzle. Journal of Finance, 39, 575-592.

42. Schildt, H. A., Zahra, S. A., \& Sillanpa, A. (2006, May). Scholarly communities in entrepreneurship research: A co-citation analysis. Entrepreneurship Theory and Practice, 399-415.

43. Schumpeter, J. A. (1934). The theory of economic development: An inquiry into profits, capital, credit, interest, and the business cycle. Cambridge: Harvard Universty Press.

44. Shane, S. (2003). A general theory of entrepreneurship. Northampton: Edward Elgar Publishing.

45. Shane, S., \& , S. (2000). The promise of entreprenurship as a field of research. Academy of Management review, 25 (1), 217-226.

46. Small Business Administration Office of Advocacy. (2008, September). Frequently Asked Questions. Retrieved October 22, 2008, from www.sba.advo

47. Stevenson, H. H., \& Jarillo-Mossi, J. C. (1986). Preserving entreprenurship as companies grow. Journal of Business Strategy, 7, 10-23.

48. Strauss, A. I., \& Corbin, J. (1998). Basics of qualitative reserach: Techniques and procedures for developing grounded theory. Thousand Oaks, CA: Sage Publications.

49. Timmons, J. A., \& Spinelli, S. (2009). New Venture Creation: Entrepreneurship for the 21st Century. New York: McGraw-Hill/Irwin.

50. Venkatarman, S. (1997). The distinctive domain of entrepreneurship research: An editor's perspective. In J. A. Katz, \& R. H. Brockhaus, Advances in entrepreneurship: Firm emergence and growth (pp. 119-138). Greenwich, CT: JAI Press.

51. Weber, M. (1904). The Protestant ethic and the spirit of capitalism. London: George Allen \& Unwin.

52. Yunus, M. (2007). Creating a world without poverty; social business and the future of capital. Philadelphia, PA: Pegasus Books.

53. Zahra, S. (2005). Entrepreneurship and disciplinary scholarship. In S. A. Alvarez, R. Agarwal, \& O. Sorenson, Handbook of Entrepreneurship Research: Interdisciplinary Perspectives (pp. 253-268). New York: Springer Science-Business Media, Inc. 


\section{APPENDIX A}

\begin{tabular}{|c|c|c|c|c|}
\hline & Pseudonym & Gender & Minority & Description \\
\hline 1 & Mark & Male & & $\begin{array}{l}\text { Investor. Managing Partner in } \$ 150 \text { million } \\
\text { Venture Capital Firm Specializing in Health } \\
\text { Sciences Investments }\end{array}$ \\
\hline 2 & Joan & Female & Yes & $\begin{array}{l}\text { Nascent. Founder of not for profit } \\
\text { organization providing services for at-risk } \\
\text { children in Southern California }\end{array}$ \\
\hline 3 & Larry & Male & & $\begin{array}{l}\text { Large Business. Founder of pre IPO venture } \\
\text { capital financed firm provided services for } \\
\text { medical professionals }\end{array}$ \\
\hline 4 & Arnold & Male & & $\begin{array}{l}\text { Public Policy/Intrapreneur. CEO of } \\
\text { nongovernmental organization promoting } \\
\text { entrepreneurship at state level. Also senior } \\
\text { executive with entrepreneurial activity inside } \\
\text { with large publicly traded media company }\end{array}$ \\
\hline 5 & Rachael & Female & Yes & $\begin{array}{l}\text { Small Business. Founder of } \$ 5 \text { million } \\
\text { company providing software services for a } \\
\text { variety of companies. }\end{array}$ \\
\hline 6 & Gary & Male & & $\begin{array}{l}\text { Nascent/Medium Business. Founder of } \$ 10 \\
\text { million providing home medical equipment } \\
\text { and services. }\end{array}$ \\
\hline 7 & Fran & Female & Yes & $\begin{array}{l}\text { Nascent/Small Business. Founder of } \$ 1 \\
\text { million company providing strategic services } \\
\text { for small businesses. }\end{array}$ \\
\hline 8 & Les & Male & Yes & $\begin{array}{l}\text { Immigrant/Large Business. Immigrant } \\
\text { founder of } \$ 250 \text { million real estate } \\
\text { development company. }\end{array}$ \\
\hline 9 & Barbara & Female & Yes & $\begin{array}{l}\text { International/Medium Business. Founder of } \\
\$ 25 \text { million company providing travel and } \\
\text { convention planning services for a number of } \\
\text { international firms. }\end{array}$ \\
\hline 10 & Victor & Male & & $\begin{array}{l}\text { International/Large Business. Founder of a } \\
\$ 400 \text { million multinational firm providing } \\
\text { information technology and software services } \\
\text { with } 2,000 \text { employees, many of which are } \\
\text { located in Asia. }\end{array}$ \\
\hline 11 & Olivia & Female & Yes & $\begin{array}{l}\text { Nascent/Small Business. Founder of } \$ 2 \\
\text { million company providing local information } \\
\text { technology services. }\end{array}$ \\
\hline 12 & Greg & Male & & $\begin{array}{l}\text { Nascent/Medium Business. Entrepreneurial } \\
\text { Partners who founded } \$ 10 \text { million web }\end{array}$ \\
\hline 13 & Joe & Male & & $\begin{array}{l}\text { hosting operation providing services lor the } \\
\text { media and entertainment industry. }\end{array}$ \\
\hline
\end{tabular}

